\title{
O preconceito e a prática profissional do assistente social: os valores e o projeto profissional crítico
}

\author{
The prejudice and the professional practic of the social assistant: the values and the \\ critical professional Project
}

\section{Gênesis de Oliveira Pereira*}

\begin{abstract}
Resumo:
O presente trabalho tem por objetivo debater as possibilidades de práticas profissionais livres de preconceito. Para a realização de tal debate, é traçada uma problematização sobre a origem dos valores, desvalores e dos preconceitos. Abordouse a especificidade do trabalho e a alienação na sociedade capitalista. Posteriormente, foi apresentado o projeto ético-político do Serviço Social, articulado ao movimento democrático vivido na sociedade brasileira. Por fim, debateu-se o preconceito e a prática profissional do assistente social, buscando elementos ético-políticos, potencialmente, capazes de combater esse desvalor, no âmbito da categoria profissional, e fortalecer o projeto profissional crítico.
\end{abstract}

Palavras-chave: Projeto ético-político. Consciência. Valores. Preconceito.

\begin{abstract}
:
This work has the purpose of to debate the possibilities of professional practices free of bias. To perform such debate, is drawn a problematization about the origin of values, disvalues and prejudices. We approach the work's especificity and the alienation in capitalist society. Posteriorly we present the ethical-political project of Social Service articulated to democratic movement experienced by brazilian society. Lastly, we discuss the prejudice and the professional practice of the social assistant, seeking theoretical elements potentially able to combat this disvalue within the category and consolidate the critical professional project.
\end{abstract}

Key-words: Ethical-political project. Consciousness. Values. Prejudice.

\section{Introdução}

O presente trabalho tem por objetivo realizar uma reflexão sobre as origens do preconceito e sobre a necessidade de uma prática profissional orientada por uma reflexão ética. A motivação para esta elaboração teórica remete ao avanço do preconceito na sociedade e, também, no interior da profissão. Diante desse cenário adverso, caracterizado pela intolerância às diferenças ou pela tolerância marcada pela indiferença, o preconceito, quando presente na prática de um agente profissional, é um elemento que restringe a

\footnotetext{
* Assistente social (UFF). Mestre em Serviço Social pela Universidade Federal do Rio de Janeiro (UFRJ). Doutorando em Serviço Social pela Universidade Estadual do Rio de Janeiro (UERJ). E-mail: genesis.oliveira@gmail.com
} 
liberdade e pode negar as necessidades sociais apresentadas pelos usuários. Com base nesses elementos, o estudo se propôs a reconstruir as mediações presentes no projeto ético-político, que permitem projetar e intervir na realidade livre de preconceitos.

No âmbito do acúmulo teórico necessário para abordar esse objeto, realizo, no item dois, uma problematização sobre a origem dos valores e dos desvalores; no terceiro item, aprofundo a reflexão sobre o trabalho e a alienação na sociedade capitalista; no quarto item, apresento a construção do projeto profissional crítico do Serviço Social e sua relação com os movimentos presentes na sociedade brasileira, e, por fim, abordo o papel da consciência na administração de valores ou devalores, momento no qual situo o preconceito e as possibilidades de uma intervenção profissional livre dessa objetivação.

Nesse sentido, o presente estudo visa a fortalecer o projeto profissional crítico, construído, coletivamente, pela categoria profissional, e a fomentar práticas profissionais, potencialmente, capazes de consolidar o projeto ético-político nos limites conjunturais e estruturais da sociedade capitalista.

\section{Os valores e desvalores}

O trabalho é a atividade fundante do ser social, o momento no qual o homem, ao transformar a natureza, dela se distancia. Este processo é mediado pela orientação teleológica, que expressa o papel ativo da consciência na busca dos meios, na projeção das finalidades e na avaliação dos resultados.

Ao transformar a natureza em valores de uso para si, por intermédio do trabalho, os homens não apenas criam e recriam modos de produção, como realizam sua própria essência. $O$ trabalho é, assim, a forma primária e privilegiada dentre as suas objetivações, ou seja, de práxis (GUERRA, 1995, p. 103).

Nessa direção, situo a gênese do valor na práxis produtiva, que coloca em movimento o processo de escolhas entre alternativas que se conectam ao dever-ser, para alcançarem a finalidade desejada. Segundo Coelho (2013, p. 265-266):

O trabalho, modelo de práxis, é sempre fonte de valor. No processo de trabalho, o homem objetiva-se e, ao final, há um produto, articulam-se teleologia e causalidade, e a satisfação das necessidades imediatas estabelece mediações que se desdobram em nova objetividade. No ato do pôr teleológico o homem, de um lado, busca os meios de trabalho e, de outro, discerne entre as alternativas 
possíveis àquela que será efetivada, escolhida. No momento da delimitação da escolha, a posição do fim é determinante e se conecta ao dever-ser e, sobre essa escolha, historicamente determinada, incidem os valores [...].

Assim, a gênese do valor conecta-se na delimitação das escolhas para alcançar os fins desejados, que, por sua vez, constitui uma relação ontologicamente articulada ao processo de busca pelos meios. Este processo é articulado, pois compõe momentos inseparáveis no ato do trabalho. De acordo com Lessa (2012 a), embora haja uma identidade entre valor e dever-ser, por estes serem partícipes do mesmo processo, o dever-ser regula as ações para a realização de um fim, enquanto que os valores incidem sobre a finalidade última e a valoração da nova objetividade criada. Segundo Costa (2012, p. 22), "é neste ato de avaliar positiva ou negativamente o resultado do trabalho que emerge o valor enquanto categoria objetiva do ser."

Ao contrário da perspectiva pós-moderna, que atrela os valores à subjetividade - sem nenhuma relação com a objetividade -, para a perspectiva ontológica lukácsiana, o valor surge como uma nova categoria no ser social, construída a partir da objetividade das relações sociais, e, portanto, todo valor é uma categoria objetiva no interior do ser social. Em outras palavras, os valores não estão dados na realidade, os valores são criados pelos homens a partir da transformação da natureza. Segundo Vazquez (2013, p. 147): “[...] os valores, em suma, não existem em si e por si independente dos objetos reais [...] nem tão pouco independente da relação com o sujeito (o homem social). Existem assim objetivamente, isto é, com uma objetividade social."

A consciência exerce um papel ativo no ato das escolhas, pois projeta as finalidades a serem alcançadas e, sobretudo, realiza escolhas valorativas acerca do problema originário da práxis. Em outras palavras, no campo das finalidades - e também dos meios - a consciência exerce um papel ativo, pois, no bojo da práxis, orienta a escolha valorativa que mensura, dentre as alternativas presentes no processo de objetivação, quais seriam as mais adequadas, mais válidas para alcançar o objetivo final. Embora a consciência exerça um papel ativo no processo de valoração, os valores não surgem de maneira abstrata na consciência. Toda consciência valora algo que, primeiramente, existe objetivamente. Nessa perspectiva, os valores são originários da práxis, o que implica reconhecer que sua objetivação é oriunda da busca dos homens por respostas às suas necessidades. Segundo 
Heller, a base para o desenvolvimento de todos os valores e ideias situa-se na explicitação das forças produtivas:

[...] consideramos como valores as forças produtivas e como explicitação dos valores a explicitação dessas forças, já que essa explicitação significa direta ou indiretamente, aquelas das capacidades humanas, na medida em que aumenta a quantidade de valores de uso - e, portanto, de necessidades humanas - e diminui o tempo socialmente necessário (HELLER, 1972, p. 8).

De acordo com Heller, a objetividade do valor funda-se na atividade ontológica primária, o trabalho, momento no qual o homem é obrigado a realizar escolhas, que, por sua vez, são sempre escolhas sobre "ideias concretas, finalidades concretas, alternativas concretas. Seus atos concretos de escolha estão naturalmente relacionados com sua atitude valorativa geral, assim como seus juízos estão ligados à sua imagem de mundo. " (HELLER, 1972, p. 14).

Reconhecer a objetividade do valor não implica desconsiderar o papel da subjetividade. Os complexos valorativos são compostos sempre por uma dupla dimensão, objetiva e subjetiva. Objetiva, pois toda escolha pressupõe uma compreensão valorativa acerca do problema, e subjetiva, pelo fato de sempre exigir decisões singulares para as demandas postas na vida cotidiana. A dupla dimensão que conforma os complexos valorativos é sempre determinada socialmente, portanto, até mesmo as escolhas singulares são permeadas pelas determinações sociais de cada época, e, assim, não se pode falar em escolhas subjetivas independentes da realidade. Nesse sentido, conforme Lessa (2012 a, p. 120):

Os valores são qualidades objetivas potencialmente presentes no serprecisamente-assim existente, potencialidade que apenas pode se atualizar no interior da relação teleologia/causalidade. Portanto, nem são puramente subjetivos nem decorrência direta da materialidade dos objetivos, mas uma dimensão ontológica puramente social, inexistente na natureza, e que corresponde a um elemento essencial - certamente não o único - da nova objetividade que consubstancia o mundo dos homens. A essência dos valores para o mundo dos homens está em que sem eles não há atos teleologicamente postos, ou seja, sem eles não há ser social. Evidentemente não estamos com isso afirmando que em Lukács o mundo dos homens possa ser reduzido aos valores ou que neles possa encontrar sua fundação enquanto esfera ontológica distinta da natureza.

Como citado anteriormente, a gênese do valor encontra-se na relação direta com as alternativas postas em movimento pela práxis, e sua materialização originária situa-se na 
avaliação da causalidade posta. No entanto, de acordo com Lukács apud Lessa (2012 a): “A fonte verdadeira e própria de tal gênesis é, ao invés, a mudança ininterrupta da estrutura social, e é por tal mudança que brotam diretamente as posições que realizam o valor." (LUKÁCS apud LESSA, 2012 a, p. 139).

Segundo Lessa (2012 a), há uma contradição aparente no pensamento de Lukács: Os valores surgem na práxis ou na "mudança ininterrupta da estrutura do ser social"? Embora as afirmações pareçam se contradizer, de acordo com Lessa (2012 a), para Lukács, a práxis é o fundamento ontológico dos valores, e a reprodução social é a gênese, historicamente determinada, de cada valor. Cabe, então, explicar essas determinações.

Reconhecer o fundamento do valor, na práxis, significa reconhecer que, sem o ato do trabalho, não há valores nem o desenvolvimento da socialidade e, portanto, não há o ser social. Porém, reconhecer o trabalho como fundamento ontológico dos valores, não implica reduzir todos os valores ao trabalho. Entre trabalho e totalidade social há uma malha de categorias que compõe a reprodução social. Por reprodução social, compreendese o momento de construção da particularidade de cada momento histórico. Conforme Lessa (2012 a), a ética, a moral e o direito são complexos que necessitam tanto do momento fundante do trabalho, quanto do momento particularizador da totalidade das mediações operantes no ser social, em cada momento histórico, para sua concretização. Nesse sentido, Lessa ressalta que:

\footnotetext{
1) Entre os fundamentos ontológicos dos valores e as gêneses de cada um deles há uma diferença fundamental, que reflete as distinções e conexões que, no plano do ser, articulam trabalho e reprodução social; e 2) se valores surgem espontaneamente na práxis social, mesmo que não se tenha consciência desse fato, não menos verdadeiro é que a forma dessa atuação e o conteúdo dos valores dependem diretamente da consciência que os homens têm de sua própria história; para sermos breves, do grau de desenvolvimento do gêneropara-si (LESSA, 2012 a, p. 140).
}

Nesse sentido, a reprodução social exerce um papel fundamental na concretização dos valores. Não inserir essa categoria no debate sobre os valores levaria a um reducionismo do valor ao trabalho, sem mediação das determinações históricas de cada momento, ou, em outras palavras, sem a categoria da reprodução social, a busca pela particularidade dos valores, em cada momento histórico determinado, como afirma Lessa, estaria fadada ao erro dos idealistas que acreditam que os valores explicam a história. 
Portanto, a busca pela particularidade histórica da origem e a realização de cada valor ocorrem na reprodução social. Dito de outro modo, a realização dos valores é determinada pela síntese dos atos singulares que conformam a totalidade social. Nesse contexto, os valores só podem surgir "a partir do desenvolvimento do ser social em direção a formas cada vez mais elevadas de sociabilidade." (LESSA, 2012 a, p. 142). As formas, cada vez mais elevadas de sociabilidade, estão ligadas ao impulso oriundo do trabalho para além de si próprio, ou seja, o avanço da sociabilidade, movido pela atividade trabalho, gera complexos sociais que não têm relação direta com a práxis produtiva.

Por sua vez os complexos valorativos, que assim vêm a ser, jogam um papel fundamental na reprodução social e, consequentemente, exercem efetiva ação de retorno sobre o desdobramento concreto da relação homem/natureza, do trabalho, da esfera econômica, enfim (LESSA, 2012 a, p. 145).

Assim, a complexificação oriunda do avanço da sociabilidade amplia os processos valorativos num sentido precisamente específico: articular as decisões individuais ao destino do gênero. É sob o solo da superação da imediaticidade do trabalho e da complexificação do ser social que se fundam as sociedades mais complexas, nas quais inúmeros processos sociais se desenvolvem sem relação direta e imediata com a práxis, cada vez mais determinadas por mediações causais.

Com base em todos os elementos, até aqui, debatidos, compreende-se por valor tudo o que contribui para o enriquecimento da essência humana, ou seja, entende-se "como valor tudo aquilo que faz parte do ser genérico do homem e contribui, direta ou mediantemente, para a explicação do ser genético." (HELLER, 1972, p. 4). No entanto, há também valores que desumanizam o homem e ferem o humano-genérico, que, segundo Heller (1972, p. 5), são os desvalores: "pode-se considerar desvalor tudo o que direta ou indiretamente rebaixe ou inverta o nível alcançado no desenvolvimento de um determinado componente essencial. "

No campo dos desvalores, está contido o preconceito, objeto deste estudo. O preconceito tem sua origem na vida cotidiana, pelo "caráter momentâneo dos efeitos, a natureza efêmera das motivações e, a fixação repetitiva do ritmo, a rigidez do modo de vida" (HELLER, 1972, p. 43). A vida cotidiana exige, para sua reprodução, juízos provisórios cotidianos, isto é, não é possível refletir sobre todas as decisões que se deve tomar na 
cotidianidade, assim, por se precisar responder, são criados juízos provisórios cotidianos, que são conceitos antecipados que, nem sempre, se confirmam no decorrer da prática humana. De acordo com Heller (1972), há uma profunda relação dos juízos provisórios com o preconceito, porém, nem todo juízo provisório é um preconceito, ao contrário, são preconceitos "os juízos provisórios refutados pela ciência e por uma experiência cuidadosamente analisada, mas que se conservam inabalados contra todos os argumentos da razão [...]." (HELLER, 1972, p. 47). Em uma sociedade cuja atividade criadora do homem é alienada, todas as suas demais objetivações encontram-se também alienadas. Aí está contida a possibilidade de acirramento e proliferação de objetivações valorativas baseadas em falsos juízos de valor, isto é, preconceitos.

Assim, até então, é possível afirmar que os preconceitos se desenvolvem na vida cotidiana e que são frutos de juízos falsos de valores. Todo juízo de valor falso ou verdadeiro necessita da categoria ultrageneralização. Como atenta Heller, necessita subsumir o mais rápido possível o singular sob alguma universalidade, e, neste processo, não é possível analisar todos os aspectos singulares. Esse processo ocorre por meio de ultrageneralizações, que são difundidas pelas experiências antecessoras. No próximo item, será analisada a especificidade do trabalho e da alienação, presentes na sociedade capitalista.

\section{Capitalismo, consciência e alienação}

Neste tópico, será abordada a alienação do trabalho no capitalismo e, consequentemente, a alienação de todas as expressões do ser social. Este percurso teórico se faz necessário para que seja possível reconstruir as mediações referente às possibilidades concretas de acesso consciente aos valores humano-genéricos, potencialmente capazes de orientar o trabalho profissional dos assistentes sociais na direção presente no projeto profissional crítico.

A sociabilidade capitalista, erguida sob as ruínas do feudalismo, funda-se na expropriação da riqueza produzida pelo trabalhador, isto é, nesta forma de organização das forças produtivas, o trabalho deixa de ser uma atividade criativa e transforma-se em uma atividade castradora das potencialidades humano-genéricas.

Como bem recorda Carlos Nelson Coutinho (1994), porém, a sociedade capitalista não surge com propostas reacionárias e dominadoras, ao contrário, a ascensão da 
sociabilidade capitalista e a busca por uma racionalidade humana do mundo colocam a burguesia, em seus primórdios, como uma classe revolucionária. ${ }^{1}$

A burguesia deixa de ser revolucionária quando se torna classe dominante e, para legitimar o desenvolvimento do capital e a ampliação da dominação sobre o homem, sua produção ideológica nega o humanismo, a razão dialética e o historicismo, e, para escamotear as mutilações da práxis sob o domínio capitalista, lança-se ao irracionalismo. Portanto, perde seu compromisso com a verdade.

A mutilação da práxis, fundamento da sociabilidade capitalista, ocorre a partir do momento em que o trabalhador vende sua força de trabalho ao capitalista, para que ele a use como queira. De acordo com Marx (1996, p. 304):

O trabalhador trabalha sob o controle do capitalista a quem pertence o trabalho. [...] o produto é propriedade do capitalista, e não do produtor direto, do trabalhador. A capitalista paga, por exemplo, o valor de um dia da força de trabalho. A sua utilização, como a de qualquer outra mercadoria, por exemplo, a de um cavalo que alugou por um dia, pertence-lhe, portanto, durante o dia todo.

O trabalhador, nos marcos do capitalismo, deixa de ser o dono de seu processo de trabalho e perde o controle sobre sua produção, isto é, ao comprar a força de trabalho, o capitalista passa a ser o detentor da capacidade de produção do trabalhador. Sob esta base, funda-se a concepção de alienação em Marx, ou seja, o trabalho, sob o controle do capitalista, retira desta atividade a possibilidade de humanizar o homem, de ampliar suas capacidades emancipatórias. Neste sentido, o trabalho se apresenta ao trabalhador como um poder estranho, que o domina ao invés de ser dominado por ele. É nesse processo que o trabalho deixa de humanizar o homem e passa a desumanizá-lo, isto é, o trabalho, como obrigação, como mercadoria, aliena suas potencialidades criativas e o gênero humano.

A produção capitalista transforma o trabalho criador, humanizador do homem, em mercadoria. Nesse processo, o homem, ao vender sua força de trabalho, o faz para sua

\footnotetext{
${ }^{1}$ Segundo Carlos Nelson (2010, p. 25): “O capitalismo, em dado momento, representou - não só no plano econômico-social, mas também no plano cultural - uma extraordinária revolução na história da humanidade. Seu nascimento e explicitação implicavam a atualização de possibilidades apenas latentes na economia feudal desenvolvida, atualização que dependia, por sua vez, da dissolução e desintegração das relações feudais de produção, de suas formas de divisão do trabalho. Esse caráter objetivamente progressista do capitalismo permitia aos pensadores que se colocavam do ângulo do novo a compreensão do real como síntese de possibilidade e realidade, como totalidade concreta em constante evolução."
} 
manutenção de reprodução diária, e não pelo valor que ela é capaz de produzir. Segundo Marx (1996, p. 311):

\begin{abstract}
A circunstância de que a manutenção diária da força de trabalho só custa meia jornada de trabalho, apesar de a força de trabalho poder operar, trabalhar um dia inteiro, e por isso, o valor que sua utilização cria durante um dia é o dobro de seu próprio valor de um dia, é grande sorte para o comprador, mas, de modo algum, uma injustiça contra o vendedor. ${ }^{2}$
\end{abstract}

Marx identifica que a criação de mais-valor se realiza na esfera de produção de mercadorias, como resultado de uma parte da jornada de trabalho não paga ao trabalhador. Assim, para Marx, parte do trabalho do operário não é pago e sim apropriado, privadamente, pelo capitalista. Essa organização societária, fundada no trabalho assalariado e na apropriação privada dos meios produtivos e da riqueza socialmente produzida, subsume e aliena a atividade criadora do homem (o trabalho) aos interesses da classe detentora dos meios de produção. Nas palavras de Konder (2009, p. 40):

Na acepção marxista, por conseguinte, a alienação é um fenômeno que deve ser entendido a partir da atividade criadora do homem nas condições em que ela se processa. Deve ser entendido, sobretudo, a partir daquela atividade que distingue o homem de todos os outros animais, isto é, a partir daquela atividade através da qual o homem produz os seus meios de vida e se cria a si mesmo: o trabalho humano.

Desse modo, Konder (2009) ressalta um problema ontológico da maior importância: a alienação do gênero humano. A sociabilidade capitalista promove a alienação do gênero, da essência humana, por meio do trabalho assalariado, que limita as capacidades criativas e emancipadoras do homem. De acordo com Marx (2007, p. 1) "o modo de vida material condiciona o desenvolvimento da vida social, política e intelectual em geral." Assim, a conformação estranhada do trabalho, própria da sociedade capitalista, implica a alienação em todas as objetivações do ser social. É nesse processo que o homem "pode imaginar-se algo mais e algo diverso de consciência da prática existente; pode imaginar que representa algo sem estar representando algo real" (MARX; ENGELS apud KONDER, 2009, p. 65).

\footnotetext{
${ }^{2}$ Embora não caiba, neste trabalho, um aprofundamento sobre essa categoria, Marx está falando sobre maisvalia absoluta.
} 
Portanto, na sociabilidade capitalista, a consciência apresenta-se divorciada da prática e está fundada na alienação.

No âmbito do preconceito, essa sociedade dividida em classes sociais erguidas sob a alienação da práxis acirra e prolifera a filiação a pensamentos pré-estabelecidos, sem questionamentos. Segundo Heller (1972), a assimilação acrítica do preconceito remete a uma maior facilidade de integração social, acirrada por uma falsa consciência forjada no desenvolvimento histórico desigual, porém, em última instância, toda adesão a qualquer preconceito exige uma escolha individual, relativamente livre, que não pode ser desconsiderada. Reconhecer que todo preconceito necessita, obrigatoriamente, da adesão do indivíduo, remete à consciência, isto é, o ato de se apropriar e elencar os valores para se compreender o mundo é uma mediação realizada na consciência, que, por sua vez, dada sua conformação, pode mediar valores emancipatórios e, também, desvalores e preconceitos que desumanizam o homem.

Dessa forma, cumpre demarcar que todo preconceito é sempre, eticamente, negativo, "porque todo preconceito impede a autonomia do homem, ou seja, diminui sua liberdade relativa diante do ato de escolha, ao deformar e, consequentemente, estreitar a margem real de alternativa do indivíduo." (HELLER, 1972, p. 59). Por um lado, o preconceito diminui as possibilidades de escolha entre alternativas, e, neste sentido, é um desvalor que desumaniza o homem e não estabelece nenhuma relação enriquecedora com o gênero humano. Por outro lado, a sociabilidade capitalista acirrou a alienação humana e aprofundou a conformação da consciência individual dissociada (e, muitas vezes, contrária) do destino do gênero humano. Nessa esfera, há uma enorme proliferação de desvalores que empobrecem o ser social.

Assim, a consciência exerce um papel ativo e não pode, de forma alguma, ser pensada apenas em nível do pensamento. A consciência incide, também, sobre a ação do homem na realidade, e, portanto, deve assumir um papel ativo de compreensão do movimento das coisas e do direcionamento da práxis. Para Lukács:

[...] ou a consciência torna-se espectador inteiramente passivo do movimento das coisas, sujeito a leis e no qual não se pode de maneira nenhuma intervir, ou considera-se como uma força que pode dominar a seu bel-prazer, subjetivamente, o movimento das coisas, em si despido de sentido (LUKÁCS apud IASI, 2011, p. 38). 
Portanto, a consciência é o espaço onde é possível apreender os valores presentes na realidade e identificar o "movimento das coisas", de modo a orientar a prática profissional dos assistentes sociais em uma perspectiva contrária ao acirramento e à proliferação dos preconceitos e a potencializar os valores defendidos no projeto profissional crítico.

\section{O projeto profissional crítico}

A construção de um projeto profissional radicalmente crítico $^{3}$, referenciado na tradição marxista, articula-se, profundamente, com o amplo movimento democratizante vivido na sociedade brasileira nos anos de 1980 - com o protagonismo dos movimentos operário e sindical -, que deram vigor, legitimidade e viabilidade social a esse projeto. Nessa direção, o mesmo se apresenta como uma resposta concreta da categoria às transformações societárias, emergentes na década de 1980, que só pôde se hegemonizar para o coletivo dos assistentes sociais devido ao avanço democrático de setores críticos que lhe deram base de sustentação social. Portanto, é preciso analisar a constituição do Projeto ético-político do Serviço Social com base nos movimentos e projetos presentes na sociedade, uma vez que os projetos profissionais, consciente ou inconscientemente, sempre fortalecem projetos de sociedade. Segundo lamamoto:

Projetos profissionais esses que são indissociáveis dos projetos societários que Ihes oferecem matrizes e valores. Projetos esses que necessitam ser historicamente identificados e explicitados as forças e sujeitos políticos que presidem a sua construção nas sociedades nacionais, como parte de um processo de lutas pela hegemonia na sociedade e na profissão (IAMAMOTO, 2008, p. 223).

No bojo do processo de renovação do Serviço Social, a categoria reconhece que a orientação dada à ação profissional pode fortalecer o capital ou o projeto de superação da sociedade capitalista, uma vez que nenhuma prática profissional é neutra. O resgate histórico da construção do projeto profissional crítico do Serviço Social permite a

\footnotetext{
${ }^{3}$ Não cabe, neste trabalho, uma abordagem sobre a disputa pela hegemonia no direcionamento da intervenção e formação da categoria profissional. Para se aprofundar nesta questão, ver Netto (1991), Ditadura e Serviço Social.
} 
visualização de que há uma vinculação entre este projeto e as lutas da classe trabalhadora, e, portanto, um posicionamento ético-político de vinculação ao projeto societário emancipador da classe explorada pelo capital. Essa vinculação do projeto profissional ao projeto societário da classe trabalhadora só foi possível após uma ampla problematização acerca da inserção do Serviço Social na divisão sócio-técnica do trabalho, ou seja, essa problematização permitiu à categoria desvelar o campo de interesses contraditórios em que se desenvolve o trabalho profissional, que, ao responder a situações concretas que se apresentam em seu trabalho, ou fortalece os sujeitos que vivenciam as mazelas da questão social em seu cotidiano, ou os interesses capitalistas, de continuidade e manutenção da desigualdade da sociedade de classe.

O Conselho Federal de Serviço Social (CFESS) reconhece que a especificidade do Serviço Social, na divisão sócio-técnica do trabalho, encontra-se "organicamente vinculada às configurações estruturais e conjunturais da questão social e às formas históricas de seu enfrentamento - que são permeadas pela ação dos trabalhadores, do capital e do Estado" (CEFESS apud IAMAMOTO, 2008, p. 183, grifo do autor).

A partir da compreensão da inserção da profissão na divisão sócio-técnica do trabalho, é possível a elaboração de um projeto profissional vinculado, ética e politicamente, aos interesses das classes trabalhadoras. Esse projeto é normatizado pela Lei de Regulamentação da profissão (Lei n. 8.662/93), pelo Código de Ética (1993) e pelas Diretrizes Curriculares (ABEPSS, 1996; MEC-SESu/CONESS, 1999), visando a assegurar uma formação profissional capaz de apreender as transformações sociais e a propor uma intervenção que favoreça e fortaleça o processo de luta das classes subalternas ${ }^{4}$.

No entanto, é necessário pontuar que a efetivação desse projeto ocorre em um cenário sócio-político adverso, de refluxo da classe trabalhadora e avanço neoliberal sobre os direitos assegurados pela Constituição de 1988. O projeto ético-político do Serviço Social depara-se com um período histórico no qual o Estado reduz suas funções nos campos dos direitos sociais, minimiza-se para a classe trabalhadora e amplia-se para o mercado. Nesse contexto, por um lado, o Estado passa parte de sua responsabilidade - principalmente, no

\footnotetext{
${ }^{4}$ Cumpre, neste trabalho, destacar, no que se refere ao projeto ético-político, sua radicalidade teórico-crítica e a abertura de uma nova forma de compreender a sociedade e a profissão na realidade capitalista, levando em consideração as particularidades da conformação do Serviço Social brasileiro.
} 
âmbito dos direitos - para o terceiro setor e para a iniciativa privada. Por outro lado, as políticas sociais, cada vez mais focalizadas e restritivas, destinam-se a selecionar os mais pobres dentre os miseráveis, ferindo, assim, o princípio da universalidade. O contexto adverso ao projeto profissional crítico requer um aprofundamento que dê visibilidade e vigor teórico para as conquistas até aqui asseguradas, e, nos limites deste trabalho, privilegia-se o combate ao preconceito, expresso no código de ética dos(as) Assistentes Sociais (p. 23), por meio do seguinte princípio: "empenho na eliminação de todas as formas de preconceito, incentivando o respeito à diversidade, à participação de grupos socialmente discriminados e à discussão das diferenças."

\section{Valores e desvalores: o preconceito e a prática profissional dos assistentes sociais}

Debater a dimensão do enfrentamento ao preconceito no interior do projeto éticopolítico do Serviço Social remete à necessidade de combater, teoricamente, a adesão a valores que desumanizam o homem. Assim, reafirmo a objetividade dos valores e o papel da consciência na reconstrução da prática social que o funda. Portanto, eles "não são categorias abstratas, mas determinação da prática social que o pensamento reconstrói e conceptualiza" (PAIVA et al., 1995, p. 164).

Na história da profissão, somente em 1993, há um posicionamento ético-político de enfrentamento ao preconceito, que se materializa no sexto princípio já abordado ao longo deste artigo. As relações nas quais os assistentes sociais se envolvem, em seu trabalho, os colocam em situações, valorativamente, delicadas e, neste cenário complexo, se atuarem referenciados em uma consciência do senso comum, estarão propícios a reproduzir valores incoerentes $^{5}$ com o projeto profissional e, no bojo deste processo, também alguns preconceitos. Em outras palavras, como profissionais inseridos na divisão sócio-técnica do trabalho, atuam sobre as múltiplas expressões da questão social, por meio das políticas sociais, junto a segmentos, socialmente, discriminados, estigmatizados e alvos de preconceito, tais como: pobres, negros, gays, lésbicas, travestis, transexuais, usuários de drogas. Certamente, conforme trabalhado no item 1, na sociedade complexificada atual,

\footnotetext{
${ }^{5}$ Compreendo por valores contrários ao projeto profissional, os desvalores que caminham na direção contrária do aprofundamento da democracia, da equidade, da cidadania, da justiça social, portanto, direção contrária ao desenvolvimento genérico do ser social.
} 
os valores que devem ser administrados para a prática junto a segmentos sociais discriminados não podem se reduzir à práxis produtiva, ao trabalho. Como assistentes sociais comprometidos com a consolidação do projeto profissional crítico, deve-se, sobretudo, desvelar a questão social que atravessa esses grupos e, também, refletir sobre a gênese histórica - dada na reprodução social - dos valores hegemônicos que incidem sobre parcelas minoritárias da sociedade, acirrando o processo de exclusão e a questão social. A partir desses elementos, pode-se intervir com base na ampliação e consolidações de direitos e, portanto, na contracorrente do preconceito.

A consciência é um aspecto constitutivo do ser social e, sob a relação ontológica entre necessidade e liberdade, é fundamental, para que se realizem escolhas de natureza valorativa, teórica e política, que incidam sobre a prática profissional e, a partir dessas escolhas, pode-se orientar a prática para o interesse da classe trabalhadora ou para a manutenção da ordem. A consciência nasce e se reproduz a partir de necessidades postas pelo senso comum se expressa no trabalho como assistentes sociais, por meio da compreensão da questão social como algo dado, que sempre existiu, e, portanto, naturalizada. Não há uma leitura crítica sobre as relações capitalistas de produção que fundam a desigualdade social e dão um significado específico para a profissão de assistente social. Nesse âmbito, estão contidas as possibilidades de mediação com valores que afastam o homem de sua genericidade. Os valores mediados pela consciência do senso comum são, em geral, valores norteados pelo moralismo, carregados de preconceitos, orientados por uma visão humanista-cristã, ou seja, valores apropriados ao longo da vida pelos sujeitos que se apresentam como cristalizados, inquestionáveis, e, mesmo refutados pela ciência, continuam a ser uma referência para o indivíduo. A consciência do senso comum reproduz a preocupante e emblemática fala de muitos assistentes sociais: "valores não se discute, cada um tem o seu." O preconceito se propaga amplamente nessa esfera e, certamente, a possibilidade de superação deste está associada ao processo de desalienação.

Só podemos nos libertar dos preconceitos se assumirmos corajosamente o contínuo processo de desalienação, o que equivale, na formulação de Gramsci à superação do senso comum: inicialmente com o bom senso e, por fim, como práxis libertária. Assim, o contraponto ao preconceito dá-se por meio do resgate da ética na perspectiva da afirmação dos indivíduos sociais, como sujeito livres, críticos e criativos [...] (PAIVA et al., 1995, p. 165). 
Os agentes profissionais precisam transcender a esfera da consciência vinculada às determinações do senso comum e a consciência precisa avançar na reflexão crítica acerca dos valores morais e, portanto, se consolidar na perspectiva ética. O projeto ético-político do Serviço Social, por meio de suas dimensões teórico-práticas, ético-políticas e técnicooperativas, tem por objetivo provocar a superação do senso comum e a construção de uma consciência crítica, isto é, formar profissionais aptos a intervir na realidade, conscientes dos limites da sociabilidade capitalista e, em última instância, estabelecer, em suas finalidades, as possibilidades de superação dessa sociedade. Nesse sentido, conforme Santos (2010, p. 49), “o máximo que se pode alcançar é uma atuação profissional de enfrentamento das expressões da 'questão social' dentro desta ordem, visando, todavia, sua superação. " (SANTOS, 2010, p. 49). Portanto, o assistente social deve intervir consciente dos limites da sociabilidade capitalista e, de acordo com as finalidades - que atribuem direção à intervenção na realidade - realizar escolhas que transcendam a dinâmica do cotidiano e possibilitem projeções que tenham por objetivo ampliar a margem de autonomia dos sujeitos. Segundo Guerra (1995, p. 14):

[...] entendemos que o exercício profissional orientado por um projeto profissional que contenha valores universalistas, baseados no humanismo concreto, numa concepção de homem enquanto sujeito autônomo, orientado por uma teoria que vise apreender os fundamentos dos processos sociais e iluminar as finalidades, faculta aos assistentes sociais a consciência de pertencer ao gênero humano e thes permite desenvolver escolhas capazes de desencadear as ações profissionais motivadas por compromissos sociocêntricos que transcendam a mera necessidade pessoal e profissional de seus agentes que se hipertrofia na esfera da cotidianidade

Nesse sentido, o combate ao preconceito necessita de uma projeção da consciência crítica para que o agente profissional possa intervir de forma ético-moral consciente, isto é, tendo clareza de que seus atos influem, concretamente, sobre os sujeitos, positiva ou negativamente, o que pode contribuir tanto para o processo de emancipação do homem quanto para a reprodução de sua alienação. Segundo Conselho Federal de Serviço Social (2012, p. 71):

A ética é parte da práxis: uma ação prática e social consciente mediada por valores emancipatórios que visa interferir na realidade social para objetivá-los. Por sua natureza, essa práxis exige um certo grau de consciência e de 
comprometimento com motivações éticas de caráter genérico: exigências que remetem ao enfrentamento de conflitos da totalidade social.

As ações profissionais vinculadas ao combate ao preconceito, que, certamente, devem ser realizadas cotidianamente, necessitam se articular ao valor ético-político central: a liberdade. Compreende-se por liberdade uma capacidade pertencente à humanidade e não ao indivíduo, isto é, é impossível ser livre individualmente se o conjunto da humanidade não for livre.

O conceito de liberdade que faz referência o Código de Ética dos Assistentes Sociais exige a sua própria redefinição apontando para uma nova direção social, que tenha o indivíduo como fonte de valor, mas dentro da perspectiva de que a plena realização da liberdade de cada um requer a plena realização de todos. Portanto, é preciso garantir as demandas que a ela se vinculam - autonomia, emancipação e plena expansão dos indivíduos sociais (PAIVA; SALES, 1995, p. 182).

Dessa maneira, com certeza, essa compreensão de liberdade não pode ser efetivada, em sua totalidade, no capitalismo. No entanto, dada a dimensão contraditória da realidade em que se insere a prática da assistência social, é possível estabelecer mediações que fortaleçam e ampliem as margens de liberdade de poder de decisão consciente dos sujeitos. No cotidiano profissional, o assistente social depara-se com decisões e escolhas valorativas distintas de suas próprias e, muitas vezes, até antagônicas. Práticas profissionais sem embasamento teórico, orientadas teleologicamente pela consciência do senso comum, tendem a reproduzir preconceitos. Esta reprodução, no trabalho profissional, além de limitar e desconsiderar a margem de escolha dos sujeitos, tende a impedir o acesso a direitos. Ao longo de minha trajetória profissional, das experiências de estágio ou supervisão acadêmica, e na relação com outros colegas de profissão, escuto, muitas vezes, profissionais que dizem: "Não tem dinheiro para comer, mas tem para fumar cigarro. "; "Fui na visita domiciliar e a casa era suja. Pobreza não é sinônimo de sujeira. "; "Sou contra adoções por casais homossexuais."; "Vem solicitar o bolsa família, mas tem celular com WhatsApp e internet." Análises sem referenciais teóricos empobrecem a intervenção da categoria na realidade social, reproduzem preconceitos, potencialmente, capazes de impedir o acesso dos usuários a serviços, direitos e conquistas humano-genéricas. Assim, de acordo com Conselho Federal de Serviço Social (2012, p. 90), 
"essas situações mostram que necessidades sociais podem ser negadas em nome do preconceito e de atitudes policialescas."

O preconceito materializa-se na prática profissional de inúmeras formas, por exemplo, através da não aceitação do nome social de pessoas trans, da não aceitação da orientação sexual homoafetiva, da criminalização e moralização da pobreza e da população negra, da negação do feminismo e apoio à reprodução da cultura machista que invisibiliza as mulheres etc... Todas essas expressões sinalizam uma prática profissional orientada por valores religiosos e humanistas cristãos, pela moralidade dominante, por práticas orientadas por uma consciência incapaz de ultrapassar a aparência fenomênica e atingir a essência dos fenômenos e incapaz de articular valores humano-genéricos para ampliar a cidadania e o respeito aos grupos socialmente discriminados. Apreensões de mundo centradas em preconceitos impactam o trabalho do assistente social por meio da negação do direito e da manutenção das desigualdades presentes na sociedade de classe.

A prática profissional orientada de acordo com o projeto ético-político exige uma consciência crítica capaz de articular as diferenças de escolha e decisões valorativas entre assistentes sociais e usuários no campo da diversidade, do pluralismo, da alteridade, da capacidade humana de liberdade, entendida como capacidade de realizar escolhas mais ou menos livres dentro dos limites da sociabilidade capitalista. Nesse sentido, o respeito à diversidade pressupõe a tolerância.

O fato de lidarmos com a efetivação de uma prática social torna premente o nosso dever de exercitar e suscitar a tolerância e o respeito diante do outro e das diferenças requisitos fundamentais para o amadurecimento da democracia e da liberdade (PAIVA; SALES, 1995, p. 196).

No entanto, como atenta Conselho Federal de Serviço Social (2012), este estudo tem como foco a tolerância positiva, isto é, a tolerância vinculada à equidade e à liberdade, a aceitação consciente das escolhas dos outros sujeitos, mesmo quando não compartilhadas pelo profissional. A tolerância negativa é a não aceitação de escolhas diferentes, mas 'toleradas' "com indiferença e isolamento" (CONSELHO FEDERAL DE SERVIÇO SOCIAL, 2012, p. 70). A intolerância, muitas das vezes, presente no trabalho profissional, se expressa de forma a negar direitos, pois toda intolerância leva a assumir "atitudes destrutivas, fanáticas, racistas. A diferença é negada; mais do que isso, buscamos destruí- 
la, excluir a identidade do outro, por meio da afirmação da nossa [...]." (CONSELHO FEDERAL DE SERVIÇO SOCIAL, 2012, p. 70).

Diante disso, deve-se ter a clareza de que os problemas presentes na objetividade social não se resolvem por meio da consciência, pois, mesmo que o profissional seja portador de consciência crítica, a emancipação da humanidade só ocorre com a libertação da práxis. Nesta perspectiva, o caminho de abertura para a conformação de uma consciência desalienada passa pelo fim do estranhamento entre o homem e o produto de seu trabalho, pois, o fim das relações capitalistas é só o início para uma vivência emancipada, porém, mesmo em uma conjuntura de trabalho desalienada, o preconceito e outros desvalores podem continuar a se reproduzir.

Com base nos elementos, até aqui expostos, acredita-se que se deve aprofundar os estudos sobre a ética profissional e problematizar a dimensão cotidiana da prática profissional, tanto na teoria como na relação com outros colegas de profissão. Por ora, cumpre reafirmar que uma prática profissional livre de preconceito é necessária para se ampliar a possibilidade de efetivação do projeto profissional e fortalecer o compromisso com a classe trabalhadora. Deve-se, para tal, estar atento para que nenhum juízo provisório de valor se sobreponha à validade teórica e filosófica da defesa dos valores humano-genéricos, por meio do humanismo concreto e da razão dialética. Portanto, o caminho para o combate à transfobia, à homofobia, ao machismo, ao racismo, ao ódio de classe e a tantas outras manifestações do preconceito, que podem atravessar a prática do assistente social e sua apreensão das expressões da questão social, situa-se no campo de uma consciência crítica, capaz de questionar os juízos provisórios e empenhada em buscar os fundamentos ontológicos dos valores necessários para a intervenção profissional, além de ser capaz de articular as determinações objetivas e subjetivas que compõem a questão social e extrapolar a racionalidade burguesa num contínuo movimento de desalienação.

É evidente, porém, que não cabe à categoria profissional do assistente social a transformação valorativa da sociedade, mas é preciso ter nítido que é possível, mesmo nas relações capitalistas, estabelecer mediações com valores emancipatórios. Assim, embora essa transformação não possa se realizar, em toda sua potencialidade, na sociedade burguesa, a partir da reflexão ética pode-se orientar a prática profissional com base em valores potencialmente emancipatórios. 


\section{Considerações finais}

O presente estudo traz algumas considerações sobre a importância da consciência no trabalho dos assistentes sociais, sua vinculação com o projeto profissional crítico e seu papel no distanciamento do preconceito.

No âmbito da prática profissional, a consciência exerce um papel ativo no que se refere à captação da realidade relatada pelos usuários e na projeção de alternativas que incidam no cotidiano dos sujeitos de modo a contribuir para o fortalecimento dos interesses da população usuária. Assim, é na consciência que se processa a interpretação da realidade relatada e, também, se dão as mediações valorativas, práticas e teóricas, que se plasmam na intervenção profissional. É necessário ter claro que não é a consciência que muda a realidade, mas a intervenção. Nesse sentido, a consciência direciona a intervenção na realidade, porém, a prioridade ontológica é da prática.

Como lembra Guerra (2007, p. 25), “como uma atividade da consciência a formulação/apropriação dos projetos profissionais exige um ser consciente.". Assim, a conformação da consciência, que permite a apropriação e a efetivação do projeto profissional e, consequentemente, uma prática profissional livre de preconceitos, remete a uma consciência crítica, orientada por valores humano-genéricos.

No percurso deste trabalho, afirmo que a não adesão a preconceitos - orientada pela clareza ético-política de vinculação ao projeto societário emancipatório - realiza-se na consciência conduzida pela reflexão crítica, isto é, uma reflexão ética é capaz de compreender as escolhas antagônicas às próprias, com base na liberdade, na tolerância positiva, na diversidade, no pluralismo. Dessa forma, pode-se contribuir para a participação ativa dos grupos socialmente discriminados.

Os desafios para a formação de profissionais livres de preconceito e, potencialmente, capazes de articular o combate do mesmo à liberdade, à tolerância, ao pluralismo, ao respeito à diversidade e à participação dos grupos socialmente discriminados, passa por uma formação teórica, valorativa e filosófica sólida, capaz de construir finalidades profissionais orientadas por uma consciência crítica. A partir de então, se é capaz de propor alternativas viáveis de ampliação da liberdade. No entanto, o atual cenário, marcado pelo crescimento do ensino à distância, pela privatização e mercantilização do ensino superior, 
pela religiosidade e barbarização das relações sociais, traz avanços do conservadorismo na profissão. Tal fato cria uma dificuldade de se romper com a consciência do senso comum, durante a formação dos agentes profissionais, o que os coloca em um terreno propício à propagação de preconceitos, de violação de direitos e desrespeito à diversidade e à liberdade. Segundo Barroco (2011, p. 212).

\begin{abstract}
A reatualização do conservadorismo é favorecida pela precarização das condições de trabalho e da formação profissional, pela falta de preparo técnico e teórico, pela fragilização de uma consciência crítica e política, o que pode motivar a busca de respostas pragmáticas e irracionalistas, a incorporação de técnicas aparentemente úteis em um contexto fragmentário e imediatista. A categoria não está imune aos processos de alienação, à influência do medo social, à violência, em suas formas subjetivas e objetivas. Isso coloca um imenso desafio ao projeto ético-político, na medida em que a sua viabilização não depende apenas da intencionalidade dos profissionais, tendo em vista as suas determinações objetivas, nem se resolve individualmente
\end{abstract}

O refluxo das forças críticas e a precarização das condições de trabalho e da formação profissional complexificam o cenário no qual intervêm os assistentes sociais. Considera-se que os impactos para o trabalho profissional, oriundos desse cenário, ampliam o número de profissionais com formação mais frágil e, portanto, com menos capacidade de criar alternativas nesse contexto adverso.

Diante desses elementos, não se pode ter uma postura fatalista, mas reconhecer o cenário no qual se desenvolve a prática profissional e criar alternativas viáveis de fortalecimento da classe trabalhadora. Assim, este estudo é uma contribuição que objetiva combater a adesão acrítica ao preconceito, no cotidiano profissional, e avançar, no interior da categoria, no que diz respeito à ampliação da liberdade dos indivíduos e ao acesso aos direitos sociais.

Além disso, acredita-se que a eliminação do preconceito não é uma meta utópica, pois, com base em uma formação adequada, todo homem pode chegar a entender a importância de cada um sentir-se como indivíduo, com suas características, peculiaridades e necessidades, sem ser ver vítima de juízos provisórios de valor.

\title{
Referências
}

BARROCO, L. Barbárie e neoconservadorismo: os desafios do projeto ético-político. Revista serviço social e sociedade, São Paulo, n. 106, 2011.

COELHO, M. A. Valores e a prática profissional do assistente social. In: MONTAÑO, C.; LUSTOSA, R. Conhecimento e sociedade: ensaios marxistas. São Paulo: Outras Expressões, 2013. 
CONSELHO FEDERAL DE SERVIÇO SOCIAL. Código de ética do (a) assistente social comentado. São Paulo: Cortez, 2012.

COUTINHO, C. N. Marxismo e política: a dualidade de poderes e outros ensaios. São Paulo: Cortez, 1994.

GUERRA, Y. A Instrumentalidade do serviço social. São Paulo: Cortez, 1995.

GUERRA, Y. O projeto profissional crítico: estratégia de enfrentamento das condições contemporâneas da prática profissional. Revista serviço social e sociedade, São Paulo, $\mathrm{n}$. 91, 2007.

HELLER, A. O cotidiano e a História. Rio de Janeiro: Paz e Terra, 1972.

IAMAMOTO, M. V. O serviço social em tempos de capital fetiche: capital financeiro, trabalho e questão social. São Paulo: Cortez, 2008.

IASI, M. L. Ensaios sobre consciência e emancipação. 2. ed. São Paulo: Expressão Popular, 2011.

KONDER, L. Marxismo e alienação. São Paulo: Expressão Popular, 2009.

LESSA, S. Mundo dos homens: trabalho e ser social. São Paulo: Instituto Lukács, 2012a.

LESSA, S. Serviço social e trabalho: Porque o Serviço Social não é trabalho? São Paulo: Instituto Lukács, 2012b.

MARX, K. Contribuição à crítica da economia política. São Paulo: Expressão Popular, 2007.

MARX, K. O capital: critica da economia política. São Paulo: Civilização Brasileira, 1996.

PAIVA, B. A. et al. Reformulação do código de ética: pressupostos históricos, teóricos e políticos. In: BONETTI, D. A. et al (Org.). Serviço social e ética: convite a uma nova práxis. São Paulo: Cortez, 1995.

PAIVA, B. A.; SALES, M. A. A nova ética profissional: práxis e princípios. IN: BONETTI, D. A. et al. (Org.). Serviço social e ética: convite a uma nova práxis. São Paulo: Cortez, 1995.

SANTOS, C. M. Na prática a teoria é outra? Mitos e dilemas na relação entre teoria, prática, instrumentos e técnicas no serviço social. Rio de Janeiro: Lúmen Júris, 2010.

VAZQUEZ, A. S. Ética. Rio de Janeiro: Civilização Brasileira, 2013. 